\title{
Elemental hydrochemistry assessment on its variation and quality status in Langat River, Western Peninsular Malaysia.
}

\begin{abstract}
This paper discusses the hydrochemistry variation and its quality status in Langat River, based on the chemistry of major ions, metal concentrations and suitability for drinking purposes. Water samples were collected from 30 different stations to assess their hydrochemical characteristics. The physico-chemical parameters selected were temperature, electrical conductivity, total dissolved solids (TDS), salinity, dissolved oxygen , $\mathrm{pH}$, redox potential, $\mathrm{HCO} 3, \mathrm{Cl}, \mathrm{SO} 4, \mathrm{NO} 3, \mathrm{Ca}, \mathrm{Na}, \mathrm{K}, \mathrm{Mg}, 27 \mathrm{Al}, 138 \mathrm{Ba}, 9 \mathrm{Be}, 111 \mathrm{Cd}, 59 \mathrm{Co}, 63 \mathrm{Cu}$, $52 \mathrm{Cr}, 57 \mathrm{Fe}, 55 \mathrm{Mn}, 60 \mathrm{Ni}, 208 \mathrm{~Pb}, 80 \mathrm{Se}$ and $66 \mathrm{Zn}$ to investigate the variation of the constituents in the river water. Most of the parameters comply with the Drinking Water Quality Standard of the World Health Organization and the Malaysian National Standard for Drinking Water Quality by the Malaysia Ministry of Health except for EC, TDS, Cl, HCO3, $\mathrm{SO} 4, \mathrm{Na}, \mathrm{Mg}, \mathrm{Al}, \mathrm{Fe}$ and Se. The results show that the Langat River is unsuitable for drinking purposes directly without treatment.
\end{abstract}

Keyword: Langat River; Surface water; Hydrochemistry; Variation of constituents; Guidelines. 